\title{
IDENTIFICATION AND CHARACTERIZATION OF FILAMENTOUS FUNGI ISOLATED FROM THE SUNFLOWER (HELIANTHUS ANNUS L.) RHIZOSPHERE ACCORDING TO THEIR CAPACITY TO HYDROLYSE INULIN
}

\author{
Cristina Maria de Souza-Motta ${ }^{1}$; Maria Auxiliadora de Queiroz Cavalcanti ${ }^{1 *}$; Maria José dos Santos Fernandes ${ }^{1}$; \\ Débora Maria Massa Lima ${ }^{1}$; João Paulo Nascimento ${ }^{1}$; Delson Laranjeira ${ }^{2}$
}

${ }^{1}$ Departamento de Micologia, Centro de Ciências Biológicas, Universidade Federal de Pernambuco, Recife, PE, Brasil. ${ }^{2}$ Departamento de Agronomia, Universidade Federal Rural de Pernambuco, Recife, PE, Brasil.

Submitted: November 05, 2002; Returned to Authors: March 13, 2003; Approved: September 30, 2003.

\begin{abstract}
Filamentous fungi able to hydrolyse inulin have been isolated from the rhizosphere of plants whose roots contain this polysaccharide. This study reports results concerning the isolation and identification of filamentous fungi from the soil used for sunflower cultivation and from the sunflower rhizosphere cultivated in field and in greenhouse. Fungi were evaluated according to their capacity to hydrolyse inulin and the variation in the diversity of these fungi during the plant's life cycle was also accessed. Forty-nine species of filamentous fungi were isolated. Penicillium and Aspergillus were the genera that presented higher number of species, nine and seven, respectively. At the end of the sunflower life cycle, cultivated both in field and in the greenhouse, a lower numbers of species were isolated. One hundred and fifty nine strains of filamentous fungi were isolated from soil and from the sunflower rhizosphere; from these, 79 (49.7\%) were able to hydrolyse inulin. There was not significant difference in the proportion of species able to hydrolyse this polysaccharide during the sunflower's life cycle, in plants cultivated in field or in greenhouse. Although the sunflower's rhizosphere is a source of filamentous fungi able to hydrolyse inulin, that might be used in biotechnological processes. This system does not present a higher density of such microorganisms. Species of Aspergillus, Chaetomium, Cunninghamella, Emericela, Eupenicillium, Fusarium, Myrothecium, Neosartorya, Neocosmospora, Penicillium and Thielavia are being related by first time as inulinase producers.
\end{abstract}

Key words: Fungi, rhizosphere, soil, inulinase, sunflower.

\section{INTRODUCTION}

The fungi coexist with other organisms due to many biotic and abiotic factors in the environment which are favorable to the occupation of a common habitat (47). The term rhizosphere is defined as the soil volume adjacent to the roots and influenced by them (26) and represents an area of intense microbial activity (46), in which the organic nutrients coming from the roots favour the development of microorganisms (25). These nutrients are originated by the descamation of cells and of exudates such as sugars, organic acids, amine compounds as well as other substances released by the roots $(6,10)$. Thus, the rhizosphere of plants that accumulate carbohydrates in the roots, as well as the plant material in decomposition are common source of a microbiota able to produce useful metabolites for industry $(20,28,43)$. Inulinaseproducing microorganisms may be selected by plating techniques $(18,39,41)$, from the rhizosphere of plants whose roots contain inulin, like Taraxacum officinarum Rupr. (lion tooth) (43), Helianthus tuberosus L. (Jerusalem artichoke) (12), Cichorium intybus L. (chicory), Dahlia pinnata Cav. (dahlia) and Helianthus annus L. (sunflower) (19), members of the

*Corresponding author. Mailing address: Av. Boa Viagem, 3376, Apto. 92. Boa Viagem. 51020-001, Recife, PE, Brasil. E-mail: xiliamac@terra.com.br 
Asteraceae. This study accessed the fungal diversity at the sunflower rhizosphere.

The inulinase (2,1-b-D-fructanohidrolase EC 3.2.1.7) hydrolyses the inulin into pure fructose, being an excellent alternative for the production of fructose syrups. This sugar is used by the food and beverage industries, besides sweeteners, and shows several advantages in comparison to sucrose, being less cariogenic, highly soluble and hygroscopic and, therefore, less prone to form crystals; has low calory content and does not cause arteriosclerosis. Furthermore, fructose may be used by diabetes patients and mask the bitter taste of saccharin $(2,5,14,43)$. Inulinases has also been employed for kidney disease diagnosis (22). With the everincreasing potential of inulinase, it was necessary either to isolate different types of microorganisms producing higher yields of inulinase (44). This work aimed at the isolation and identification of filamentous fungi from soil used for sunflower cultivation and the sunflower rhizosphere from plants cultivated in field and in greenhouse. It was evaluated the diversity of fungi in the sunflower rhizosphere cultivated in field and in greenhouse during with the plant life cycle. Microorganisms were also characterized according to their capacity to hydrolyse inulin.

\section{MATERIALS AND METHODS}

\section{Sunflower seeds}

Sunflower seeds (variety Embrapa 122-V2000) were supplied by the Centro National de Pesquisa de Soja - Embrapa (Empresa Brasileira de Pesquisa Agropecuária), Londrina/PR.

\section{Sunflower cultivation}

Sunflower cultivation in the field was carried out by the Empresa Pernambucana de Pesquisa Agropecuária (IPA), Unidade Experimental de Pesquisa (UEP), in Itapirema/GoianaPE, using natural soil. One hundred plants were distributed in ten lines containing ten plants each. The distance between the lines was $100 \mathrm{~cm}$ and between the plants $50 \mathrm{~cm}$. The soil was kept humid up to the end of the sunflower life cycle of 100 days (1.5 L of water per plant every 4 days). Sunflower cultivation in the greenhouse was performed by the Departamento de Micologia, Centro de Ciências Biológicas (CCB), Universidade Federal de Pernambuco (UFPE). Twenty $5 \mathrm{~kg}$ pots were filled up with soil (hydromorphic podzol type, $\mathrm{pH} 5.4$ ), $6 \mathrm{mg} \mathrm{dm}^{-3}$ of $\mathrm{P}$ and $0.06,0.15,1.85,0.35 \mathrm{cmol}_{\mathrm{c}} \mathrm{dm}^{-3}$, respectively of $\mathrm{K}, \mathrm{Al}, \mathrm{Ca}$ and $\mathrm{Mg}$, originated from the Empresa Pernambucana de Pesquisa Agropecuária (IPA), Unidade Experimental de Pesquisa (UEP). The soil used for the sunflower cultivation was analyzed for the presence of filamentous fungi and considered as control of cultivation $\left(\mathrm{T}_{0}\right)$. In each pot three seeds were planted and the soil kept humid up to the end of the sunflower life cycle (100 days), using $500 \mathrm{~mL}$ of water per plant every four days. After fifteen days, the two less developed plants were taken from each pot.

\section{Samples from the sunflower rhizosphere}

Samples from the sunflower rhizosphere (soil adjacent to the roots) were collected in plastic bags within: $25,50,75$ and 100 days of growth. The field and greenhouse rhizosphere $(25 \mathrm{~g})$ of each plant was utilized for the isolation of fungi (five repetitions for each experiment).

\section{Isolation, purification and identification of the fungi}

The fungi were isolated according to Warcup (45). The soil or rhizosphere samples $(25 \mathrm{~g}$ ) were suspended in $225 \mathrm{~mL}$ of sterilized distilled water (1:10 dilution) and subsequently $10 \mathrm{ml}$ of this suspension was added into $990 \mathrm{~mL}$ of sterilized distilled water. Petri dishes containing the Sabouraud Agar medium (23) plus chloranphenicol (100 $\left.\mathrm{mg} \mathrm{L}^{-1}\right)$ and Bengal Rose $\left(50 \mathrm{mg} \mathrm{L}^{-1}\right)$ were inoculated with $1 \mathrm{~mL}$ of the 1:1000 diluted soil suspension. The plates were kept at room temperature $\left(\cong 28^{\circ} \mathrm{C}\right)$ and the growth of the colonies was accompanied up to $72 \mathrm{~h}$. Fragments of the individual colonies were transferred separately to the same medium containing $50 \mathrm{mg} \mathrm{L}^{-1}$ of chloranphenicol and the growth was accompanied for $72 \mathrm{~h}$. The strains were identified after growth on Czapek Agar and Potato Dextrose Agar (PDA) medium (23), by observing its macroscopic characteristics (colour, texture appearance and diameter of the colonies) and microscopic (microstructures), according to Baijal and Mehrotra (1), Bissett (4), Domsch et al. (11), Pitt (33), Hammill (17), Raper and Fennell (34), Rifai (35), Samuels et al. (36), Schipper (38) and Sutton (42).

\section{Identification of the inulinase producing strains}

One hundred fifty nine strains of filamentous fungi isolated from the control soil from the Empresa Pernambucana de Pesquisa Agropecuária (IPA), Unidade Experimental de Pesquisa (UEP) and rhizosphere of sunflower during the plant's life cycle, cultivated in field and in greenhouse were mantained in Czapek agar medium (Aspergillus and Penicillium) and PDA (other genera). Fragments of seven days old cultures were transferred to the center of a Czapek agar plate, containing $10 \mathrm{~g} \mathrm{~L}^{-1}$ of inulin instead of $10 \mathrm{~g} \mathrm{~L}^{-1}$ sucrose (I medium), $10 \mathrm{~g} \mathrm{~L}^{-1}$ glucose as positive controls (C+ medium) and without carbon source as negative control (C- medium). The plates were incubated at room temperature and the diameter of the colonies measured after seven days to evaluate the cell growth. Results for the I medium, were compared to the $\mathrm{C}$ - and $\mathrm{C}+$ media results. The colonies relative growth in the inulin medium (Tx) was calculated by $\mathrm{Tx}=\mathrm{I} \times 100 / \mathrm{C}+$, where I represents the diameter of the colony in I and $\mathrm{C}+$ the diameter of the colony in $\mathrm{C}+$ medium according to Cordeiro Neto et al. (9). Inulinase producing strains were evaluated by the measurement of the colonies diameters on I medium, their 
mycelium characteristics and sporulation. The strains that were unable to grow on I medium or presented a poor growth and reduced sporulation in I medium, in comparison to $\mathrm{C}$ - medium were considered unable to degrade inulin. Experiments were performed in duplicate.

\section{Statistical analysis}

The Qui-square test was used (48) to evaluate a differential distribution in the number of species of filamentous fungi, and in the frequency of species able or unable inulin degradation during the sunflower 100 days life cycle. The Sorensen Coefficient was used [Ss] (21) to verify the similarity between the fungi species isolated from the rhizosphere of sunflower cultivated in field and in greenhouse.

\section{RESULTS AND DISCUSSION}

From the control soil $\left(\mathrm{T}_{0}\right)$ used to grow sunflower and from the sunflower rhizosphere cultivated in field and in greenhouse, 49 species were isolated. From the control soil $\left(T_{0}\right) 25$ species of filamentous fungi were isolated, 21 belong to Deuteromycotina; two belong to Ascomycotina and two to Zygomycotina. From the rhizosphere of sunflower cultivated in field and in greenhouse, 37 and 32, respectively (Table 1). Among the isolated species from the sunflower rhizosphere cultivated in field, 30 belong to Deuteromycotina, five belong to Ascomycotina, and two to Zygomycotina. Among the isolated species from rhizosphere of the greenhouse, 24 belong to Deuteromycotina, six belong to Ascomycotina, and two to Zygomycotina. The lower number of isolated species from the control soil $\left(\mathrm{T}_{0}\right)$ may be due to reduced number of these samplings (five), in comparison to the number of isolation procedures performed with each of the other assayed sources: five samplings from $\mathrm{T}_{25} ; \mathrm{T}_{50} ; \mathrm{T}_{75}$ and $\mathrm{T}_{100}$, respectively from the sunflower rhizosphere, both grown in field and greenhouse (40 samples), instead of five $T_{0}$ analyzed samplings. These results agree with those found by Silva et al. (40), concerning the prevalence of fungi strains of the Deuteromycotina, isolated from tomato seeds and tomato rhizosphere. Santos et al. (37) reported similar results as to the predominance of Deuteromycotina found in sugarcane rhizosphere, by analyzing 142 samples obtained from 22 plantation sites, spread over several regions of the Pernambuco State (Brazil). Cordeiro Neto et al. (9), reported similar results on the distribution of 50 species of fungi, isolated from rhizosphere soils of Asteraceae plant, grown in Moji-Guaçu (São Paulo/Brazil). According to Garret (15), the techniques used to count microorganisms by direct observation at the microscope or by serial dilution and plating, usually done to isolate fungi, show distinct predominance of imperfect fungi or Deuteromycotina. As to the isolated genera, was observed a prevalence of Penicillium (nine) and Aspergillus (seven) species. There has also been a significant difference as to the time elapsed in the experiment, shown by a proportional decrease of isolated species, reaching their lowest number at $\mathrm{T}_{100}$, from field $\left(\mathrm{c}^{2}=13.52 ; \mathrm{g} . \mathrm{L}=4 ; \mathrm{p}\right.$ $<0.05)$ and greenhouse ( $c^{2}=10.4 ;$ g.L $\left.=4 ; \mathrm{p}<0.05\right)$ sunflower rhizospheres. According to Cardoso et al. (6), Hale and Moore (16) and Westover et al. (46), this fact is probably due to the largest exudation by roots of organic compounds like sugars, organic acids and amine compounds, which is higher in the beginning of the plants growth. Cooke (8) pointed out that in the biodegradation process, fungi strains do act separately or in cooperation or ever in antagonism to other organisms. Fungi represent some of the more active organisms of the soil population, and some species may secrete antibiotics or toxins that can eliminate competitors and, besides being killed in some cases. These features may explain the higher number of species found at the beginning of the sunflower's growth stage.

In this study, the samples from control soil $\mathrm{T}_{0}$ and from rhizosphere of sunflower cultivated both in field and greenhouse presented several common species: Acremonium strictum, Aspergillus niger, A. niveus, A. viride-nutans, Cunninghamella elegans, Eupenicillium javanicum, Fusarium oxysporum, $F$. solani, Humicola fuscoatra, Penicillium citreonigrum, $P$. oxalicum, $P$. vinaceum, $P$. waksmanii and Thielavia terricola. Some species were found only in the control soil $\mathrm{T}_{0}$ samples as Penicillium fellutanum and Rhizopus microsporus, whereas the rhizosphere of sunflower cultivated in the field presented Aspergillus brevipes, Curvularia senegalensis, Emericela nidulans, Fusarium heterosporium, F. lateritium, Sordaria sclerogenia and Phoma leveillei, and from rhizosphere of sunflower cultivated in the greenhouse, resulted in Eupenicillium brefeldianum, Neucosmospora vasinfecta and Penicillium restrictum.

The similarity found between the fungi species isolated from the control soil $\mathrm{T}_{0}$, and those isolated from the sunflower rhizosphere during the plant's life cycle was less pronounced at $\mathrm{T}_{100}$ growth stage, both in field cultivation (28.6\%) as those from cultivation in greenhouse $(41.0 \%)$. There was also a reduced similarity by comparing the species isolated from sunflower rhizosphere, at $\mathrm{T}_{100}$, both from sunflower cultivated in field and in greenhouse (41.7\%) (Table 2). According to Parkinson et al. (32) young roots are colonized initially by a diversity of the soil fungi, which after some days, are substituted by a more restricted mycobiota staying the same until the senescence of the roots. On the other hand, the decrease of the number of species isolated, found in the sunflower rhizosphere cultivated in greenhouse was not constant. After 50 days of growth, there was little variation in the number of species, fact that probably occurred due the plants being maintained in pots for the remaining cultivation period, therefore exposing the plants against adverse environmental conditions. 
Table 1. Filamentous fungi isolated from the control soil $\mathrm{T}_{0}$ and from the sunflower rhizosphere with 25, 50, 75 and 100 days of cultivation, in field and in greenhouse.

\begin{tabular}{|c|c|c|c|c|c|c|c|c|c|}
\hline \multirow[t]{2}{*}{ Species } & \multirow{2}{*}{$\begin{array}{l}\text { Soil } \\
\left(\mathrm{T}_{0}\right)\end{array}$} & \multicolumn{4}{|c|}{$\begin{array}{c}\text { Field } \\
\text { Time (days) }\end{array}$} & \multicolumn{4}{|c|}{$\begin{array}{l}\text { Greenhouse } \\
\text { Time (days) }\end{array}$} \\
\hline & & 25 & 50 & 75 & 100 & 25 & 50 & 75 & 100 \\
\hline Acremonium strictum W. Gams & $\mathrm{X}$ & - & $\mathrm{X}$ & - & - & $\mathrm{X}$ & - & - & - \\
\hline Alternaria tenuissima (Kunze ex Pers.) Wiltishire & - & - & - & - & $\mathrm{X}$ & - & - & - & - \\
\hline Aspergillus brevipes Smith & - & $\mathrm{X}$ & - & - & - & - & - & - & - \\
\hline A. fumigatus Fresenius & $\mathrm{X}$ & - & - & - & - & - & $\mathrm{X}$ & $\mathrm{X}$ & - \\
\hline A. niger van Tieghem & $\mathrm{X}$ & $\mathrm{X}$ & $\mathrm{X}$ & $\mathrm{X}$ & $\mathrm{X}$ & $\mathrm{X}$ & $\mathrm{X}$ & $\mathrm{X}$ & $\mathrm{X}$ \\
\hline A. niveus Blochwitz & $\mathrm{X}$ & $\mathrm{X}$ & $\mathrm{X}$ & $\mathrm{X}$ & - & $\mathrm{X}$ & $\mathrm{X}$ & $\mathrm{X}$ & - \\
\hline A. sydowi Bain. and Sart. Thom and Church & $\mathrm{X}$ & - & - & - & - & - & - & - & - \\
\hline A. terreus Thom & - & - & $\mathrm{X}$ & - & - & - & - & - & $\mathrm{X}$ \\
\hline A. viride-nutans Ducker and Thrower & $\mathrm{X}$ & $\mathrm{X}$ & $\mathrm{X}$ & $\mathrm{X}$ & $\mathrm{X}$ & $\mathrm{X}$ & $\mathrm{X}$ & $\mathrm{X}$ & - \\
\hline Chaetomium cupreum Ames & - & $\mathrm{X}$ & $\mathrm{X}$ & $\mathrm{X}$ & - & $\mathrm{X}$ & $\mathrm{X}$ & $\mathrm{X}$ & - \\
\hline Cladosporium cladosporioides (Fresen.) de Vries & - & $\mathrm{X}$ & $\mathrm{X}$ & $\mathrm{X}$ & $\mathrm{X}$ & - & - & $\mathrm{X}$ & - \\
\hline Cunninghamella elegans Lendner & $\mathrm{X}$ & - & $\mathrm{X}$ & - & $\mathrm{X}$ & $\mathrm{X}$ & - & - & - \\
\hline Curvularia eragrostidis (P. Henn.) J. A. Meyer & - & - & - & - & $\mathrm{X}$ & - & $\mathrm{X}$ & $\mathrm{X}$ & $\mathrm{X}$ \\
\hline C. lunata var. aerea (Batista, Lima \& Vasconcelos) M.B.Ellis & - & - & - & - & - & $\mathrm{X}$ & - & - & - \\
\hline C. pallescens Boedijn & $\mathrm{X}$ & - & - & - & - & $\mathrm{X}$ & - & - & - \\
\hline C. senegalensis (Speg.) Subram. & - & - & $\mathrm{X}$ & - & - & - & - & - & - \\
\hline Emericela nidulans (Eidam) Vuillemin & - & - & - & $\mathrm{X}$ & - & - & _ & - & - \\
\hline Eupenicillium brefeldianum (Dodge) Stolk \& Scott & - & - & - & - & - & - & - & $\mathrm{X}$ & - \\
\hline E. javanicum (van Beyma) Stolk \& Stolk & $\mathrm{X}$ & $\mathrm{X}$ & $\mathrm{X}$ & $\mathrm{X}$ & - & $\mathrm{X}$ & $\mathrm{X}$ & - & - \\
\hline Fusarium heterosporium Nees ex Fr. & - & $\mathrm{X}$ & - & - & - & - & - & - & - \\
\hline F. lateritium Nees & - & - & - & - & $\mathrm{X}$ & - & - & - & - \\
\hline F. oxysporum Schlecht. Emend Snyd. \& Hans. & $\mathrm{X}$ & - & $\mathrm{X}$ & $\mathrm{X}$ & - & $\mathrm{X}$ & $\mathrm{X}$ & $\mathrm{X}$ & $\mathrm{X}$ \\
\hline F. oxysporum var. redolens (Wollenus) Gordon & $\mathrm{X}$ & - & - & - & - & - & - & - & $\mathrm{X}$ \\
\hline F. solani (Mart.) Appel \& Wollenw. Emend Snyd. \& Hans. & $\mathrm{X}$ & $\mathrm{X}$ & $\mathrm{X}$ & - & - & $\mathrm{X}$ & $\mathrm{X}$ & - & - \\
\hline Humicola fuscoatra Traaen & $\mathrm{X}$ & $\mathrm{X}$ & $\mathrm{X}$ & - & - & $\mathrm{X}$ & - & $\mathrm{X}$ & $\mathrm{X}$ \\
\hline Myrothecium roridum Tode ex Steudel & $\mathrm{X}$ & $\mathrm{X}$ & - & - & - & - & - & - & - \\
\hline Neosartorya fisheri (Wehmer) Malloch \& Cain & - & - & - & - & - & $\mathrm{X}$ & - & - & - \\
\hline Neocosmospora vasinfecta E. F. Sm. & - & - & - & - & - & - & - & - & $\mathrm{X}$ \\
\hline Penicillium citreonigrum Dierckx & $\mathrm{X}$ & $\mathrm{X}$ & $\mathrm{X}$ & - & - & $\mathrm{X}$ & - & - & - \\
\hline P. fellutanum Biourge & $\mathrm{X}$ & - & - & - & - & - & - & - & - \\
\hline P. janthinelum Biourge & $\mathrm{X}$ & $\mathrm{X}$ & - & - & - & - & - & - & - \\
\hline P. oxalicum Currie and Thom & $\mathrm{X}$ & $\mathrm{X}$ & $\mathrm{X}$ & - & $\mathrm{X}$ & $\mathrm{X}$ & - & $\mathrm{X}$ & $\mathrm{X}$ \\
\hline P. restrictum Gilman \& Abbott & - & - & - & - & - & $\mathrm{X}$ & $\mathrm{X}$ & - & - \\
\hline P. variabile Sopp & $\mathrm{X}$ & - & - & - & - & $\mathrm{X}$ & - & - & - \\
\hline P. verruculosum Peyronel & - & $\mathrm{X}$ & $\mathrm{X}$ & $\mathrm{X}$ & - & $\mathrm{X}$ & $\mathrm{X}$ & $\mathrm{X}$ & $\mathrm{X}$ \\
\hline P. vinaceum Gilman \& Abbott & $\mathrm{X}$ & - & - & $\mathrm{X}$ & - & - & $\mathrm{X}$ & $\mathrm{X}$ & $\mathrm{X}$ \\
\hline P. waksmanii Zaleski & $\mathrm{X}$ & - & $\mathrm{X}$ & - & $\mathrm{X}$ & - & $\mathrm{X}$ & $\mathrm{X}$ & $\mathrm{X}$ \\
\hline Pestalotiopsis guepinii (Desm.) Stey. & $\mathrm{X}$ & $\mathrm{X}$ & $\mathrm{X}$ & $\mathrm{X}$ & - & - & - & - & - \\
\hline Phoma leveillei Boerema \& Bollen & - & $\mathrm{X}$ & $\mathrm{X}$ & $\mathrm{X}$ & - & - & - & - & - \\
\hline Rhizopus microporus van Tieghem & $\mathrm{X}$ & - & - & - & - & - & - & - & - \\
\hline R. oryzae Went \& Prinsen Geerligs & - & $\mathrm{X}$ & $\mathrm{X}$ & $\mathrm{X}$ & $\mathrm{X}$ & $\mathrm{X}$ & $\mathrm{X}$ & $\mathrm{X}$ & $\mathrm{X}$ \\
\hline Robillarda sessilis (Saccardo) Saccardo & - & - & $\mathrm{X}$ & - & - & - & - & - & - \\
\hline Sordaria sclerogenia Fields \& Grear & - & $\mathrm{X}$ & - & - & - & - & - & - & - \\
\hline Thielavia terricola (Gilman \& Abbott) Emmons & $\mathrm{X}$ & $\mathrm{X}$ & - & - & - & $\mathrm{X}$ & - & $\mathrm{X}$ & $\mathrm{X}$ \\
\hline Torula caligans (Batista \& Upadhyay) M. B. Ellis & - & $\mathrm{X}$ & - & - & - & - & - & - & - \\
\hline Trichoderma aureoviride Rifai & $\mathrm{X}$ & - & $\mathrm{X}$ & - & - & - & - & - & - \\
\hline T. harzianum Rifai & - & $\mathrm{X}$ & - & - & - & $\mathrm{X}$ & $\mathrm{X}$ & $\mathrm{X}$ & $\mathrm{X}$ \\
\hline T. saturnisporum Hammill & - & - & - & $\mathrm{X}$ & - & $\mathrm{X}$ & - & - & - \\
\hline T. virens (Miller, Giddens \& Foster) Von Arx & - & $\mathrm{X}$ & - & - & - & - & $X$ & $\mathrm{X}$ & - \\
\hline Total & 25 & 23 & 22 & 14 & 10 & 22 & 16 & 18 & 14 \\
\hline
\end{tabular}

$\mathrm{X}$, Isolated species. 
Table 2. Sorensen Coefficient Similarity (\%) between the species of filamentous fungi isolated from the control soil $\left(\mathrm{T}_{0}\right)$ and from the sunflower rhizosphere with $25,50,75$ and 100 days, cultivated in field and in greenhouse.

\begin{tabular}{crcccc}
\hline Field (\%) & \multicolumn{5}{c}{ Greenhouse (\%) } \\
\hline Time (Days) & \multicolumn{1}{c}{0} & 25 & 50 & 75 & 100 \\
\hline 0 & 100.0 & 59.6 & 43.9 & 46.5 & 41.0 \\
25 & 50.0 & 57.8 & 51.3 & 58.5 & 37.8 \\
50 & 59.6 & 63.6 & 52.6 & 55.0 & 44.4 \\
75 & 35.9 & 50.0 & 60.0 & 56.2 & 35.7 \\
100 & 28.6 & 31.2 & 38.5 & 50.0 & 41.7 \\
\hline
\end{tabular}

\section{Enzymatic characterization of fungi strains according to their capacity to hydrolyse inulin}

From the 159 assayed fungi strains, 79 (49.7\%) were able to hydrolyse inulin: 12 from control soil $\mathrm{T}_{0}$ followed by 31 and 36 from the sunflower rhizosphere cultivated in field and in greenhouse, respectively (Table 3). During the sunflower's life cycle the strains able to hydrolyse inulin were distributed as follows: from the isolated strains of the field, $8(57.1 \%)$ strains from $\mathrm{T}_{75}$, followed by $11(50.0 \%)$ in $\mathrm{T}_{50}, 9(33.1 \%)$ in $\mathrm{T}_{25}$ and $3(30.0 \%)$ in $\mathrm{T}_{100}$. From the isolated strains of the greenhouse, $10(66.7 \%)$ in $\mathrm{T}_{50}$, followed by $8(61.5 \%)$ in $\mathrm{T}_{100}, 8(53.3 \%)$ in $\mathrm{T}_{75}$ and $10(45.4 \%)$ in $\mathrm{T}_{25}$ (Table 3 ). There were no distinct differences related to the proportion of species characterized as able to hydrolyse inulin during the sunflower's life cycle, for both the field $\left(c^{2}=4.127 ; \mathrm{g} . \mathrm{L}=4 ; \mathrm{p}<0.05\right)$ and greenhouse $\left(\mathrm{c}^{2}=6.895 ; \mathrm{g} . \mathrm{L}\right.$ $=4 ; \mathrm{p}<0.05)$. Nevertheless, the results show a higher percentage of fungi strains characterized as able to hydrolyse inulin obtained from 50 and 75 days of cultivation of the sunflower in field and from 25 and 100 days of cultivation of the sunflower in greenhouse. According to Cardoso et al. (6) the liberation of exudates occur when the roots suffer an injury through abrasion of rough soil particles. This may also release root fragments that represent potential substrates to fungi, being therefore, a way of these microorganisms obtaining inulin as a carbon source in the rhizosphere. Furthermore, filamentous fungi can use different substrates beyond those derived from plants, as arthropod shells, nematodes, among other biological materials. The presence of fungi strains that do not hydrolyse inulin in the sunflower rhizosphere may be explained by the diversity of substrates from biological origin that exist next to the roots, and that can be used by them.

Aspergillus niger, A. niveus, A. terreus, Chaetomium cupreum, Cladosporium cladosporioides, Cunninghamella elegans, Eupenicillium javanicum, Fusarium heterosporium, Fusarium oxysporum, F. oxysporum var. redolens, F. solani, Humicola fuscoatra, Myrothecium roridum, Neosartorya fischeri, Neocosmospora vasinfecta, Penicillium citreonigrum, $P$. janthinelum, $P$. restrictum, $P$. variabile, $P$. verruculosum, $P$. vinaceum and Thielavia terricola presented better development in the I medium (growth rate $=100 \%$ ), thus considered as capable to hydrolyse inulin. Several Aspergillus and Penicillium species are known as inulinase producer $(3,9,13,27,29,30,43,44)$. $C$. elegans, P. verruculosum, Pestalotiopsis guepinii and Rhizopus oryzae isolated from the Viguiera aff. robust (Asteraceae) rhizosphere by Cordeiro Neto et al. (9), showed a different behavior from those species described in this study, isolated from the sunflower rhizosphere. However, Aspergillus fumigatus, Penicillium oxalicum and Trichoderma aureoviride isolated from the sunflower rhizosphere were not able to hydrolyse inulin, according to data obtained by Cordeiro Neto et al. (9). Cladosporium cladosporioides presented a 100\% growth rate on medium containing inulin, thus able to degrade inulin. This species was used by Lacerda Filho (24) to verify the capacity of inulinase production in medium prepared with extract of sunflower roots, obtaining a percent of $71 \%$ of enzyme production. Some species presented different behaviors during the sunflower's life cycle, as to the inulinase producing capacity. This behavior suggests that the genetical and physiological characteristics differ among different strains of the same fungi species. Some data on Rhizopus microsporus and R. oryzae strains disclosed that they were not able to grow on the media used for the enzymatic characterization, suggesting that the composition of the medium didn't supply the physiological needs of these species. This study provided the first data on the inulinase producing capacity of Aspergillus niveus, A. terreus, Chaetomium cupreum, Cunninghamella elegans, Emericela nidulans, Eupenicillium javanicum, Fusarium heterosporium, F. oxysporum var. redolens, Myrothecium roridum, Neosartorya fischeri, Neocosmospora vasinfecta, Penicillium verruculosum, P. vinaceum and Thielavia terricola.

The species characterized as able or unable to hydrolyse inulin were deposited in the Collection of Culture Micoteca URM, Departamento de Micologia, Universidade Federal de Pernambuco, Recife-PE, Brazil.

The results attained in this study, conduced by herein described experimental conditions, suggest that the Deuteromycotina (anamorphs fungi) are the fungi with higher occurrence in the soil at the Unidade Experimental de Pesquisa (UEP)/IPA, Goiana-PE and in the sunflower rhizosphere cultivated in field and greenhouse, and that Aspergillus and Penicillium species are more frequent than species of other genera. Furthermore, the obtained data indicate that the sunflower rhizosphere may interfere with the diversity of fungi, besides at the beginning of the sunflower's life cycle, the rhizosphere manifested a higher species diversity. The sunflower rhizosphere may be a source of species of filamentous fungi able to hydrolyse inulin, intending to find useful species to biotechnological processes. However, the sunflower rhizosphere does not concentrate fungi able to hydrolyse inulin during the entire plant's life cycle. 
Table 3. Growth rate (\%) regarding capacity to hydrolyse inulin by filamentous fungi strains, isolated from the control soil $\left(\mathrm{T}_{0}\right)$ and from the sunflower rhizosphere cultivated in field and in greenhouse during the plant life cycle.

\begin{tabular}{|c|c|c|c|c|c|c|c|c|c|c|}
\hline \multirow{3}{*}{$\mathrm{N}^{\mathrm{o}}$} & \multirow{3}{*}{ Species } & \multirow{3}{*}{$\begin{array}{l}\text { Soil } \\
\left(\mathrm{T}_{0}\right)\end{array}$} & \multirow{2}{*}{\multicolumn{8}{|c|}{ Growth rate $(\%)$}} \\
\hline & & & & & & & & & & \\
\hline & & & 25 & 50 & 75 & 100 & 25 & 50 & 75 & 100 \\
\hline 1 & Acremonium strictum & 0 & - & 0 & - & - & 0 & - & - & - \\
\hline 2 & Alternaria tenuissima & - & - & - & - & 0 & - & - & - & - \\
\hline 3 & Aspergillus brevipes & - & 0 & - & - & - & - & - & - & - \\
\hline 4 & A. fumigatus & 0 & - & - & - & - & - & 67.4 & 0 & - \\
\hline 5 & A. niger & 93.4 & 90.8 & 100 & 92.3 & 100 & 100 & 88.6 & 100 & 92.2 \\
\hline 6 & A. niveus & 100 & 100 & 100 & 100 & - & 100 & 100 & 100 & - \\
\hline 7 & A. sydowi & 0 & - & - & - & - & - & - & - & - \\
\hline 8 & A. terreus & - & - & 100 & - & - & - & - & - & 100 \\
\hline 9 & A. viride-nutans & 0 & 0 & 0 & 0 & 0 & 0 & 0 & 0 & - \\
\hline 10 & Chaetomium cupreum & - & 100 & 0 & 100 & - & 100 & 100 & 100 & - \\
\hline 11 & Cladosporium cladosporioides & - & 100 & 100 & 100 & 100 & - & - & 100 & - \\
\hline 12 & Cunninghamella elegans & 100 & - & 94.4 & - & 100 & 0 & - & - & - \\
\hline 13 & Curvularia eragrostidis & - & - & - & - & 0 & - & 0 & 0 & 0 \\
\hline 14 & C. lunata var. aerea & - & - & - & - & - & 0 & - & - & - \\
\hline 15 & C.pallescens & 0 & - & - & - & - & 0 & - & - & - \\
\hline 16 & C. senegalensis & - & - & 0 & - & - & - & - & - & - \\
\hline 17 & Emericela nidulans & - & - & - & 100 & - & - & - & - & - \\
\hline 18 & Eupenicillium brefeldianum & - & - & - & - & - & 0 & - & 0 & - \\
\hline 19 & Eupenicillium javanicum & 100 & 0 & 94.7 & 0 & - & - & 100 & - & - \\
\hline 20 & Fusarium heterosporium & - & 100 & - & - & - & - & - & - & - \\
\hline 21 & Fusarium lateritium & - & - & - & - & 0 & - & - & - & - \\
\hline 22 & F. oxysporum & 100 & - & 100 & 100 & - & 100 & 100 & 100 & 100 \\
\hline 23 & F. oxysporum var. redolens & 100 & & - & - & - & - & - & - & 100 \\
\hline 24 & Fusarium solani & 100 & 97.3 & 100 & - & - & 85.1 & 100 & - & - \\
\hline 25 & Humicola fuscoatra & 0 & 100 & 100 & - & - & 100 & - & - & - \\
\hline 26 & Myrothecium roridum & 100 & 100 & - & - & - & - & - & - & - \\
\hline 27 & Neosartorya fisheri & - & - & - & - & - & 100 & - & - & - \\
\hline 28 & Neocosmospora vasinfecta & - & - & - & - & - & - & - & - & 100 \\
\hline 29 & Penicillium citreonigrum & 0 & 0 & 100 & - & - & 0 & - & - & - \\
\hline 30 & P. fellutanum & 0 & - & - & - & - & - & - & - & - \\
\hline 31 & P. janthinelum & 100 & 0 & - & - & - & - & - & - & - \\
\hline 32 & P. oxalicum & 0 & 0 & 0 & - & 0 & 0 & - & 0 & 0 \\
\hline 33 & P. restictum & - & - & - & - & - & 0 & 100 & - & - \\
\hline 34 & P. variabile & 98.0 & - & - & - & - & 100 & - & - & - \\
\hline 35 & P. verruculosum & - & 100 & 100 & 100 & - & 100 & 100 & 100 & 100 \\
\hline 36 & P. vinaceum & 100 & - & - & 100 & - & - & 100 & 100 & 100 \\
\hline 37 & P. waksmanii & 0 & - & 0 & - & 0 & - & 0 & 0 & 0 \\
\hline 38 & Pestalotiopsis guepinii & 0 & 0 & 0 & 0 & - & - & - & - & - \\
\hline 39 & Phoma leveillei & - & 0 & 0 & 0 & - & - & - & - & \\
\hline 40 & Rhizopus microporus & 0 & - & - & - & - & - & - & - & \\
\hline 41 & R. oryzae & - & 0 & 0 & 0 & 0 & 0 & 0 & 0 & 0 \\
\hline 42 & Robillarda sessilis & - & - & 0 & - & - & - & - & - & - \\
\hline 43 & Sordatia sclerogenia & - & 0 & - & - & - & - & - & - & - \\
\hline 44 & Thielavia terricola & 85.7 & 0 & - & - & - & 100 & - & 100 & 90.9 \\
\hline 45 & Torula caligans & - & 0 & - & - & - & - & - & - & - \\
\hline 46 & Trichoderma aureoviride & 0 & - & 0 & - & - & - & - & - & - \\
\hline 47 & T. harzianum & - & 0 & - & - & - & 0 & 0 & - & 0 \\
\hline 48 & T. saturnisporum & - & - & - & 0 & - & 0 & - & - & - \\
\hline \multirow[t]{4}{*}{49} & T. virens & - & 0 & - & - & - & - & - & - & - \\
\hline & Total tested strains & 25 & 23 & 22 & 14 & 10 & 22 & 15 & 15 & 13 \\
\hline & Total positive strains & 12 & 9 & 11 & 8 & 3 & 10 & 10 & 8 & 8 \\
\hline & $\%$ positive strains & 48.0 & 33.1 & 50.0 & 57.1 & 30.0 & 45.4 & 66.7 & 53.3 & 61.5 \\
\hline
\end{tabular}




\section{RESUMO}

\section{Identificação e caracterização de fungos filamentosos isolados de rizosfera de girassol (Helianthus annus L.) de acordo com a capacidade de hidrolisar inulina}

Fungos filamentosos capazes de hidrolisar inulina tem sido isolados de rizosfera de plantas que acumulam esse polissacarídeo nas raízes. Este estudo compreendeu o isolamento e identificação de fungos filamentosos do solo utilizado para o cultivo do girassol e da rizosfera de girassol cultivado em campo e em casa de vegetação, a fim de verificar se há variação na diversidade destes fungos ao longo do ciclo de vida da planta. $O$ fungos foram também caracterizados quanto a capacidade de hidrolisar inulina. Das quarenta e nove espécies de fungos filamentosos isoladas, Penicillium e Aspergillus foram os gêneros que apresentaram maior número de espécies, nove e sete, respectivamente. No final do ciclo de vida do girassol, cultivado tanto em campo quanto em casa de vegetação, foi isolado um menor número de espécies. Cento e cinquenta e nove amostras de fungos filamentosos, isoladas do solo e da rizosfera de girassol e destas $79(49,7 \%)$ foram capazes de hidrolisar inulina. Não houve diferença significativa quanto a proporção de espécies capazes ou não de hidrolisar esse polissacarídeo, ao longo do ciclo de vida do girassol, cultivado tanto em campo quanto em casa de vegetação. Embora a rizosfera de girassol seja uma fonte de fungos filamentosos capazes de hidrolisar inulina, que podem ser utilizados em processos biotecnológicos, ela não atua de modo a concentrar fungos com esta característica. Espécies de Aspergillus, Chaetomium, Cunninghamella, Emericela, Eupenicillium, Fusarium, Myrothecium, Neosartorya, Neocosmospora, Penicillium and Thielavia estão sendo relatados pela primeira vez como produtores de inulinase.

Palavras-chave: Fungos, rizosfera, solo, inulinase, girassol.

\section{REFERENCES}

1. Baijal, U.; Mehrotra, B.S. The genus Cunninghamella - a reassessment. Sydowia, 33:1-13, 1980.

2. Bajpai, P.; Margaritis, A. Immobilization of Kluyveromyces marxianus cells containing inulinase activity in open pore gelatin matrix: 2. Application for high fructose syrup production. Enzyme Microb. Tech., 7:459-469, 1985.

3. Barthomeuf, C.; Regerat, F.; Pourrat, H. Production of inulinase by a new mold of Penicillium rugulosum. J. Ferment. Bioeng., 72:491494, 1991

4. Bissett, J. A revision of the genus Trichoderma. III. Section Pachybasium. Can. J. Bot., 69:2373-2420, 1991.

5. Burcke, C. Enzyme in fructose manufacture. In: Birch, G.G.; Blakebrough, N.; Parker, K.J. (eds.). Enzyme Food Process., Applied Science Publishers Ltd., London, 1981, p.51-72.

6. Cardoso, E.J.B.N.; Tsai, S.M.; Neves, M.C.P. Microbiologia do solo. Sociedade Brasileira de Ciência do Solo, 1992, 360p.
7. Castro, G.R.; Baigorí, M.D.; Siñeriz, F. A plate technic for screening of inulin degrading microorganisms. J. Microbiol. Methods, 22:51$56,1995$.

8. Cooke, W.B. The Ecology of fungi. CRC Press Inc.: Boca Raton, Florida, 1979, 274p.

9. Cordeiro Neto, F.; Pessoni, R.A.B.; Figueiredo-Ribeiro, R.C.L. Fungos produtores de inulinases isolados da rizosfera de asteráceas herbáceas do Cerrado (Moji-Guaçu, SP, Brasil). R. Bras. de Ci. Solo, 21:149153, 1997

10. Cur, E.A.; Truelove, B. The rhizosphere. Springer-Verlag, New York, 1986, 152p.

11. Domsch, H.H.; Gams, W.; Anderson, T.H. Compendium of soil fungi. Editora IHW - Verlag V. I. San Francisco, 1993. 859p.

12. Echeverrigaray, S.; Tavares, F.C.A. Atividade de inulinase em leveduras e fermentações de extratos de Helianthus tuberosos L. Rev. Microbiol., 16:127-131, 1985.

13. Ettalibi, M.; Baratti, J.C. Molecular and kinetic properties of Aspergillus ficuum inulinases. Agric. Biol. Chem., 54:61-68, 1990.

14. Fuchs, A.; Bruijn, J.M.; Niedeveld, C.J. Bacteria and yeast as possible candidates for production of inulinases and levanases. Antonie Leeuwenhoek, 51:333-351, 1985.

15. Garret, S.D. Soil fungi and soil fertility. Pergamon Press, Oxford, 1976, 165p

16. Hale, M.G.; Moore, L.D. Factors affecting root exudations. II. 19701978. Adv. Agron., 31:93-124, 1979.

17. Hammill, T.M. Paecilomyces cavisporis sp. nov., Trichoderma saturnisporum sp. nov. and other noteworthy soil fungi from Georgia. Mycologia, 62:107-121, 1970.

18. Hankin, L.; Anagnostakis, S.L Use of solid media for detection of enzyme production by fungi. Mycologia, 67:597-607, 1975.

19. Kierstan, M. Studies on enzymatic methods for extration of inulin from Jerusalem artichokes. Enzyme Microb. Technol., 5:445-448, 1983.

20. Kim, M.K.; Kim, Y.H.; Kim, H.R.; Kim, B.I.; Byun, S.M.; Uhm, T.B. Thermal stability of an acidic inulinase from Scytalidium acidophilum. Biotechnol. Lett., 16:965-966, 1994.

21. Krebs, C.J. Ecological Methodology. Addison Wesley Longmann, New York, 1999, 620p

22. Kuehnle, H.F.; Von Dahl, K.; Schmidt, F.H. Fully enzymatic inulin determination in small volume samples without deproteinisation. Nephron, 62:104-107, 1992.

23. Lacaz, C.S.; Porto, C.; Martins, J.E.C. Micologia Médica: fungos, actinomicetos e algas de interesse médico. Savier-EDUSP, São Paulo, 1991, 695p.

24. Lacerda Filho, A.M. Investigação de inulase de fonte microbiológica. Pernambuco, 1987, 110p. (Dissertação de Mestrado em Bioquímica, Universidade Federal de Pernambuco).

25. Lynch, J.M. 1990. Introduction: Some consequences of microbe rhizosphere for plant and soil. In: Cur, E.A.; Truelove, B. The rhizosphere. Springer-Verlag. New York, 1986, p.1-10.

26. Metting, B.F. Soil microbial ecology. Marcel Dekker, Nova Iorque, 1993, 382p.

27. Nakamura, T.; Shitara, A.; Matsuda, S.; Matsuo, T.; Suiko, M.; Ohta, K. Production, purification and properties of an endo-inulinase of Penicillium sp. TN-88 that liberated inulotriose. J. Ferment. Bioeng., 84:313-318, 1997.

28. Nam, S.W.; Yoda, K.; Yamasaki, M. Secretion and localization of invertase and inulinase in recombinant Saccharomyces cerevisiae. Biotechnol. Lett., 15:1049-1054, 1993.

29. Ongen-Baysal, G.; Sukan, S.S., Vassilev, N. Production and properties of inulinase from Aspergillus niger. Biotechnol. Lett., 16:275-280, 1994.

30. Onodera, S.; Shiomi, N. Purification and substrate specificity of endo-type inulinase from Penicillium purpurogenum. Agric. Biol. Chem., 72:491-494, 1991. 
31. Park, D. The ecology of terrestrial fungi. In: Ainsworth G.C.; Sussman, A.S. (eds.) The fungi, v.3. The fungal population, Academic Press, New York, 1968, p.5-39.

32. Parkinson, D.; Taylor, G.S.; Pearson, R. Studies on fungi in the root region. I. The development of fungi on young roots. Plant Soil, 19:332-349, 1963.

33. Pitt, J.I. A laboratory guide to common Penicillium species. Commonwealth scientific and Industrial Research Organization Division Food Processing, Australia, 1988, 187p.

34. Raper, K.B.; Fenell, D.I. The genus Aspergillus. Robert and Krieger, Malabar Florida, 1975, 686p.

35. Rifai, M.A. A revision of the genus Trichoderma. Mycol. Papers, 116:1-56, 1969.

36. Samuels, G.J.; Petrini, O.; Kuhls, K.; Lieckfeldt, E.; Kucicek, C.P. The Hypocrea scheinitzii complex and Trichoderma sect. Longibrachiatum. Stud. Mycol., 41, 1998.

37. Santos, A.C.; Cavalcanti, M.A.Q.C.; Fernandes, M.J.S. Fungos isolados da rizosfera da cana-de-açúcar da zona da Mata de Pernambuco. $R$. Bras. Bot., 12:23-29, 1989.

38. Schipper, M.A.A. A revision of the genus Rhizopus. Stud. Mycol., 25:1-34, 1984.

39. Selvakumar, P.; Pandey, A. Solid state fermentation for the synthesis of inulinase from Staphylococcus sp. and Kluyveromyces marxianus. Process Biochem., 34:851-855, 1999.
40. Silva, M.I.L.; Cavalcanti, M.A.Q.C.; Lima, D.M.M. Fungos na rizosfera de sementeiras de tomate. Fitopatol. Bras., 15(4):323326, 1990.

41. Su, Y.C.; Sheu, C.S.; Chien, J.Y.; Ma, K.K. Isolation and identification of microorganisms capable of producing beta-fructofuranosidase with transfructosylating activity. Proc. Nat. Sci. Coun. Rep. China Part B Life Sci., 14:114-121, 1990.

42. Sutton, B.C. The Coelomycetes fungi imperfect with picnidia acervili and stromata. Commonwealth Mycological Institute, England, 1980, $696 \mathrm{p}$.

43. Vandamme, E.J.; Derycke, D.G. Microbial inulinases: fermentation process, properties and applications. Adv. Appl. Microbiol., 29:139$176,1983$.

44. Viswanathan, P.; Kulkarni, P.R. Enhancement of inulinase production by Aspergillus niger van Thieghen. J. Appl. Bacteriol., 78:384-386, 1995.

45. Warcup, J.H. The soil plate method for isolation of fungi from soil. Nature 117-118, 1950.

46. Westover, K.M.; Kennedy, A.C.; Kelley, S.E. Patterns of rhizosphere microbial community structure associated with co-occurring plant species. J. Ecol., 85:863-873, 1997.

47. Wicklow, D.T.; Carroll, G.C. The fungal community, its organization and role in the ecosystem. Inc. Marcel Dekker, New York, 1981, 855 p.

48. Zar, J.H. Biostatistical Analysis. Prentice-Hall Internetional, Inc. Oxford, 1984, 718p. 